\title{
The Promise and Problems of Precambrian Paleosols
}

\author{
by Greg Retallack, David Grandstaff and Michael Kimberley
}

\begin{abstract}
"Weathering profiles" or "regoliths," in Precambrian rocks are now increasingly recognized as fossil soils or paleosols. Studies on them are beginning to use the standard techniques of soil science, despite many problems of interpretation due to their usually deformed and metamorphosed condition. Nevertheless, as for geologically younger paleosols, those of Precambrian age may reveal much about climates, organisms, parent materials, topography, and time for soil formation in the distant past. This review is a contribution to IGCP Project 157 on the relationships between early organic evolution and mineral and energy resources.
\end{abstract}

\section{Introduction}

Paleosols are like fossil skeletons of animals (Nikiforoff, 1943), in the sense that both were once living and developing at the surface of the earth. Only their hard parts are commonly preserved, but from these remains much can be learned of the past. Just as a fossil may bear evidence of the organism's former diet or habitat, so can factors involved in the formation of a soil be interpreted from paleosols. Following the memorable simplification of Hans Jenny (1941), soil formation is a function of five main factors: climate, organisms, topographic relief, parent material and time. Although their effects commonly overlap or are difficult to

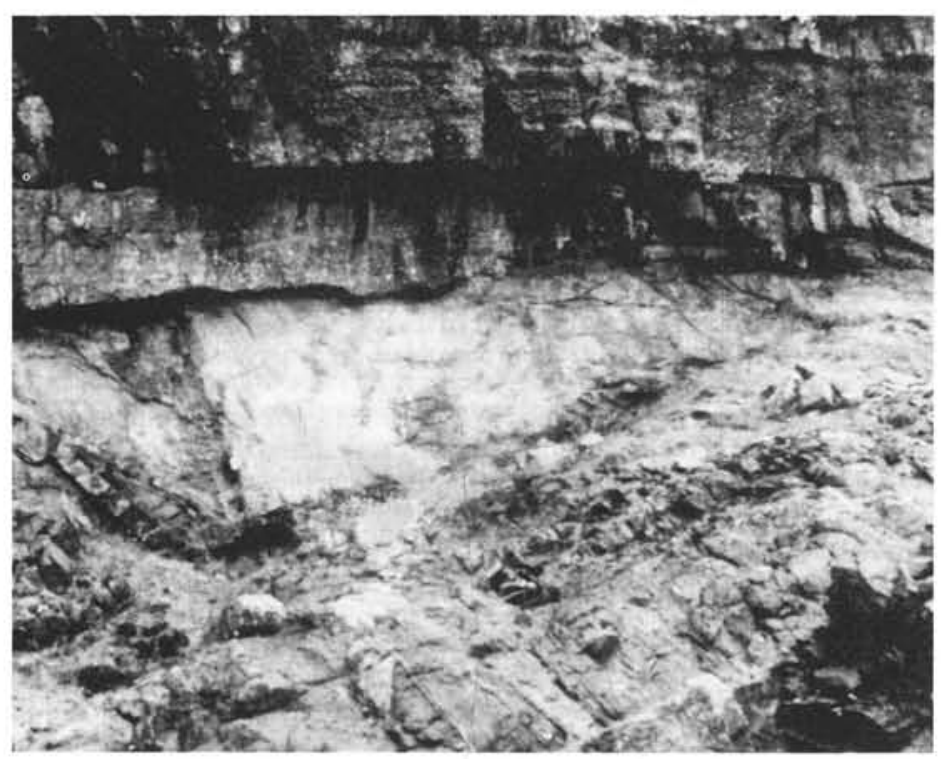

Figure l: A 1 Ga-old paleosol developed on steeply dipping Lewisian gneiss with pegmatite veins and unconformably overlain by flat-lying Torridonian alluvial fan deposits. The paleosol is the pale-coloured (bleached) zone above the rock platform in the foreground, and is reddened at its very top. Width of view about $5 \mathrm{~m}$. Near Shiegra, northwest Scotland (photo by G.J.R., see Williams, 1968). decipher, evidence of these aspects of former environments can be found in many buried soil profiles (Retallack, 1981). Precambrian paleosols may thus provide evidence of climate, including temperature, rainfall and chemical composition of the early atmosphere.

Fossil teeth, bones, and shells also are useful for establishing stratigraphic relationships. Studies of fossil soils are now widely applied to Quaternary sediments (Birkeland, 1974; North American Commission of Stratigraphic Nomenclature, 1983), as well as in older rocks (Ortlam, 1971).

Despite the promise offered by the study of paleosols (paleopedology), very little been written about them, especially those as old as the Precambrian. There are certainly interpretive problems, but we believe that two former problems, one social and one semantic, can now be put aside. The discipline of soil science, or pedology, has long been the preserve of agronomists and geographers. However, few agronomists have concerned themselves with Precambrian weathering. Neither have many geologists considered applying pedological theory to the interpretation of Precambrian paleoenvironments, though this is now changing. The semantic problem is, however, more complex.

\section{Were They Soils?}

"Soil" means different things to different people. To a civil engineer it is unconsolidated material that can be moved without recourse to blasting or other forms of quarrying. To a farmer it is productive, tillable land. Some geologists and soil scientists make a distinction between physically and chemically weathered material (weathering profiles or regoliths) and biologically altered materials (true soils). Other soil scientists regard only those materials penetrated by the roots of vascular land plants as soil (Buol and others, 1980).

Because biological activity has not been readily apparent in their formation, Precambrian weathering profiles have most frequently been termed "regoliths" rather than "soils." However, some Precambrian weathering profiles are now known to exhibit typical structures (Gay and Grandstaff 1980) and micromorphology (Kroonenberg, 1978) of soil. As shown below, there is also some evidence that living organisms may have been present in Precambrian soil profiles. It is not easy to distinguish the effects of biological and purely physico-chemical weathering, for microbes have profound physical and chemical effects. Furthermore, over the sweep of Precambrian time there are indications that biologically induced changes in the physical and chemical environment were very important (Cloud, 1976; Schopf, 1983). Labelling Precambrian weathering profiles as "regoliths," when those of Phanerozoic age are referred to as "soils," is begging the important scientific question of the advent of life and its role in modifying the Earth's surface.

The definition of soil is best left general: material at the surface of a planet or similar body, altered in place by physical, chemical, or biological agencies or by combinations of them. This broad definition applies to almost all of the materials usually labelled soil, though it departs from 
engineering use. Once the term soil is agreed upon, there is little difficulty defining paleosols as soils of the past, covered by deposits of floods, landslides, or other sedimentary agencies (buried paleosols), remaining exposed to very different soil forming factors than those operating earlier in their formation (relict paleosols), or uncovered after burial (exhumed paleosols).

There remain problems in distinguishing paleosols from other kinds of alteration zones, such as those formed by hydrothermal solutions (e.g. Kalliokoski, 1975, 1977). Identification of an altered horizon as a paleosol requires careful examination of stratigraphic associations, rock textures, and variation in mineral assemblages and chemical composition. Buried Precambrian paleosols have undergone varying degrees of diagenesis or metamorphism, which may result in alteration or destruction of soil textures, re-equilibration of minerals (e.g. destruction of primary clay minerals), changes in oxidation state of elements such as iron, and possibly metasomatic changes in bulk chemistry. The nature and effect of these changes must be understood before accurate interpretations can be made.

\section{Field Recognition}

Both soils and paleosols ean be considered modified surfaces; this is one key to their recognition in the field. Except where removed by erosion, both are laterally continuous and have a sharp, of ten erosionally truncated upper surface. Below this upper contact soils change, grading ultimately into unaltered parent material (Fig. 1). In modern soils the modifications are so variable as to defy simple characterization. Some modifications are very distinctive, as in the case of a paleosol that is conspicuously different in colour, texture or grain size from the associated layers. For example, some Archean and Proterozoic paleosols developed on basalt or ultramafic rock exhibit an unusual bright lime-green colour.

Fossil root traces and burrows are useful features for the recognition of fossil soils younger than Silurian. Older paleosols should also be examined, not only for traces of non-vascular plants, but also for burrows of soft-bodied organisms of the type found in the Cambrian Burgess Shale or late-Precambrian Ediacara fauna. It seems possible that algae or other organisms may have been present in or on Precambrian soils (Campbell, 1979). Discovery of early evidence of multicellular soil organisms would be of great interest.

A final consideration in the recognition of Precambrian paleosols concerns the time over which they are presumed to have formed. Almost all known Precambrian paleosols are major geological unconformities (Figs. 1 and 2), and additional examples may still be discovered by interpreting existing geological maps. Unfortunately, these unconformities represent much more time than needed to form a soil, and many features of the associated paleosols may be relicts of climatic or other conditions very different from those existing prior to burial. Interpretation of past conditions from such paleosols is also hampered by the way in which unconformities are commonly altered, for example by groundwater, after burial (Retallack, 1981). Although paleosols in Phanerozoic alluvial sequences have proved good evidence of past environments (Retallack, 1983), it may be that well developed soils did not form on Precambrian floodplains (Schumm, 1977). However, from observations of early Paleozoic paleosols (Fig. 3), we are optimistic that a determined search for paleosols in Precambrian fluvial and deltaic sedimentary sequences will prove worthwhile.

\section{Paleosol Textures}

Soils have characteristic structures and textures. Although structures of parent rock tend to persist in weakly developed and waterlogged soils, where these are well-developed the bedding, schistosity, or crystal structure of the parent material is progressively obliterated as new soil structures develop. Compared to many parent materials, soil appears
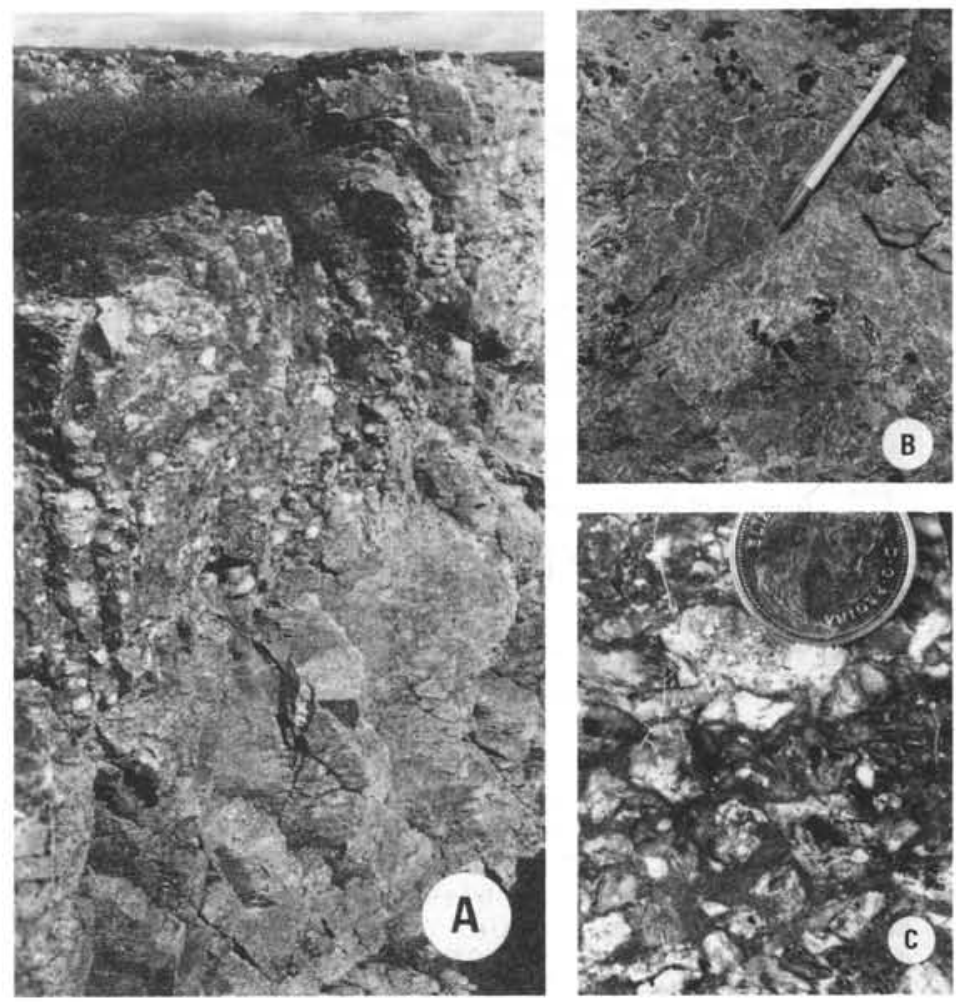

Figure 2: Basal conglomerate of the Thelon Formation (circa $1.0 \mathrm{Gal}$ capping a paleosol (up to $60 \mathrm{~m}$ thick in places) developed in Archaean augen gneiss. Central Thelon Plain, N.W.T., Canada. (See LeCheminant et al., 1983). A - General view. Conglomerate is $3 \mathrm{~m}$ high. B - Close-up of illite and silica-filled shrinkage cracks in the upper part of the paleosol. C - Close-up of weathered augen gneiss in the transition zone to fresh rock, showing kaolinized feldspar megacrysts in a hematite-clay-silica matrix. Photos by J.A. Donaldson and J.R. Chiarenzelli.

massive to hackly. On close inspection this ean be seen to result from a complex three-dimensional system of cracks and associated filling or altered material (cutans) and the natural clods of earth defined by them (peds). The accepted nomenclature for soil structures is intimidating but important for effective description and interpretation of soils and paleosols (Brewer, 1976).
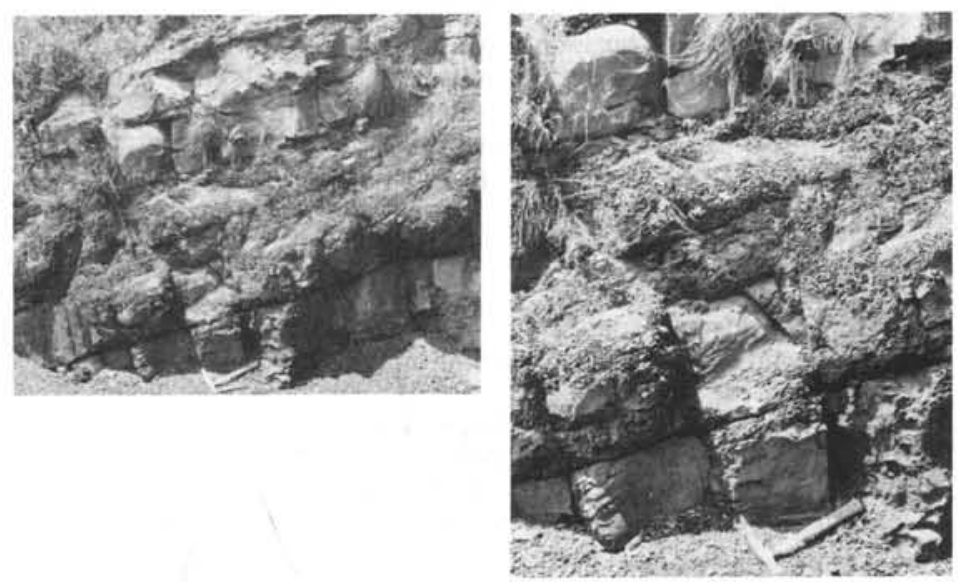

Figure 3: Paleosols (hackly, dark-red claystone) inter-bedded with fluvial paleochannels llight-coloured, cross-bedded sandstone) in the Late Ordovician (Ashgillian) Juniata Formation, Potters Mills, Pennsylvania (photo by G.J.R.). Close-up shows the sharp and irregular gradational base of the paleosol. 

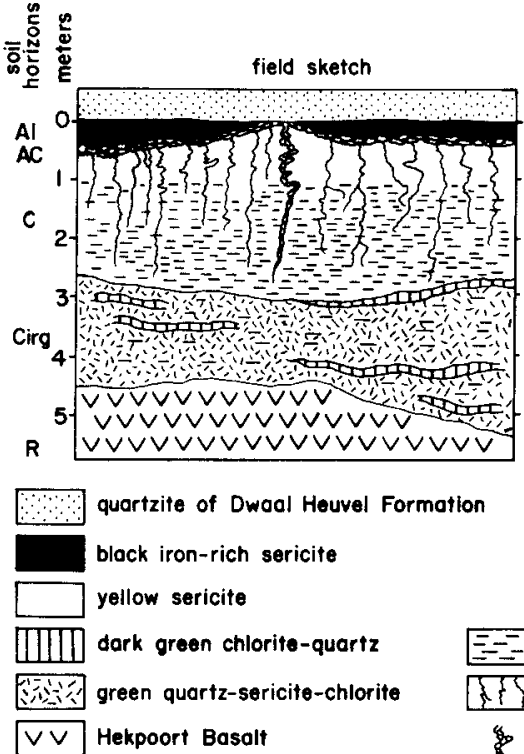

Figure 4: Stratigraphic section, mineralogical composition, grain size distribution and sample numbers of a $2.2 \mathrm{Ga}$ paleosol developed on the Hekpoort Basalt and unconformably overlain by the fluvial Dwaal Huevel Formation, near Waterval Onder, Transuaal Imodified from Button, 1979, with addition of grain size-data from G.J.R.).

Large-scale features such as boundaries between different soil horizons may be best observed in the field. Textures resulting from the destruction of primary rock fabric and the development of soil peds are best studied in thin sections or oriented polished slabs. Microscopic features, such as alignment of minerals in cutans, require petrographic thin sections. Some care must be taken in interpretation of microscopic fabrics to determine the order of formation of different features. The orientation of primary clay minerals may have been altered or destroyed if they were recrystallized during metamorphism. Similarly, stresses due to compaction or tectonism may cause reorientation of clay minerals.

Some soils and fossil soils also have characteristic microscopic textures. Elongate areas of oriented clay forming a loose network in a matrix of unoriented, flecked clay, called sepic plasmic fabric, are an indication of well-drained and well-developed soils (Brewer, 1976; Brewer and Sleeman, 1969). The texture of clayey sediments, by contrast, usually shows consistently horizontally-aligned clay. Other structure and textures found in soils and paleosols are not so distinctive. For example some contain crystals, nodules, and concretions, features also found in sediments and sedimentary rocks (Brewer, 1976).

Thin sections are of use not only for textural information, but also for mineralogical indications of soil development. Mechanical analyses for grain-size distribution routinely performed in the analysis of modern soils are, of course, inappropriate for lithified and metamorphosed paleosols, but point-counting can be used to determine variations in grain size and mineralogical composition within a paleosol profile (Fig. 5). Changes in mineralogy and chemistry in paleosols are primary indicators of the degree and nature of soil formation as well as of subsequent diagenesis or metamorphism.

\section{Chemical Approaches}

Chemical analyses of major and trace elements, including rare-earth element patterns, may shed much light on the nature of Precambrian soils. The stability of minerals and the solubility and mobility of aqueous species are greatly affected by environmental factors such as $\mathrm{pH}$ and oxidation state. Therefore, their concentration and distribution of elements may be indicators of conditions under which paleosols formed. Ideally, chemical analyses of paleosols should be compared with those of modern soils with known characteristics. Unfortunately, however, comparable whole-rock analyses of modern soils have long been abandoned in favour of analysis only of the elements freely available to plants and animals, since these determine the fertility and other important characteristics of the soil. Usually only a few elements extractable by reagents (such as iron by sodium dithionite) are determined. Such partial analyses are of little use in lithified and otherwise altered Precambrian paleosols. There are, to be sure, many full chemical analyses of modern soils from an earlier era of soil science (Marbut, 1935), but this data base is in need of modernization and amplification.

Chemical variations within altered zones should allow paleosols to be distinguished from other types of alteration zones. Subaerial weathering usually results in leaching and progressive loss of cations such as $\mathrm{Na}, \mathrm{Ca}$, and $\mathrm{Mg}$. Retention of $\mathrm{Mg}$ throughout an altered horizon, for example, might indicate that it was formed by hydrothermal alteration rather than by subaerial weathering.

There is still little agreement on how chemical analyses of Precambrian paleosols should be presented and manipulated. Ideally, determination of the amount and type of chemical weathering in a soil or paleosol should be done by calculation of gains and losses of material from a constant volume. However, most paleosols have undergone compaction, the amount of which is generally unknown. Unless compaction is minor or corrections can be made (Button, 1979) such volume calculations cannot be undertaken. In these cases chemical analyses may be normalized relative to a chemical component that is assumed to be conserved during during weathering, usually $\mathrm{TiO}_{2}$ (Kalliokoski, 1975; Button, 1979), $\mathrm{Al}_{2} \mathrm{O}_{3}$ (Gay and Grandstaff, 1980), or even $\mathrm{ZrO}_{2}$ (Schau and Henderson, 1983). In many cases choice of one normalizing element will yield similar results to others. However, leaching may preferentially remove one element in solution, or illuviation may cause either $\mathrm{Al}$ or $\mathrm{Ti}$ to be moved through the profile in clay minerals or colloids. In such cases choice of the proper normalizing element may be critical.

Various molar ratios are of ten used to compare relative intensities of chemical weathering in different localities (Birkeland, 1974; Brewer, 1976; Retallack, 1983). Common ratios used are that of $\mathrm{Al}_{2} \mathrm{O}_{3}$ to $\mathrm{SiO}_{2}$ or to the sum of $\mathrm{K}_{2} \mathrm{O}+\mathrm{Na}_{2} \mathrm{O}+\mathrm{CaO}+\mathrm{MgO}$. Such ratios have the advantage of expressing several analytical values as a single number (Birkeland, 1974). However, care must be taken not to use components whose concentration may have been significantly altered subsequent to soil formation. For example, the $\mathrm{SiO}_{2}$ concentration in paleosols may be different from its initial amount due to addition of silica cement during lithification.

In some previous studies, chemical analyses have formed the basis for interpretating Precambrian soils (e.g. Rankama, 1955). While chemical analyses alone may provide invaluable evidence of the degree and kind of weathering, it is important that they be supported by textural, petrographic, and field evidence.

\section{Evidence of Early Life}

The microfossil record of life in the oceans now extends back 3500 million years, almost as far back as the sedimentary rock record itself. Most speculation on the origin of life has centered on the roles of the atmosphere and ocean in prebiotic synthesis, concentration, and organization of organic molecules (Schopf, 1983). It seems likely that soils were also involved in events leading to the origin of living organisms (Nussinov and Vehkov, 1978; Bohn et al., 1979). Soils are the principal sites of clay formation, and clays or zeolites formed during weathering may have acted as templates or catalysts for the formation of complex organic molecules. Moreover, soil solutions can contain much higher concentrations of salts, phosphate, metals and organic matter than can ocean 
or pond waters. The proportion of the four most abundant eations $(\mathrm{Ca}, \mathrm{Mg}, \mathrm{Na}$, and $\mathrm{K})$ in soils is more like that of animals (dominated by $\mathrm{Ca}$ ) than that of the ocean (dominated by $\mathrm{Na}$ ). Solutions rich in clay, metals, organic bases and a single enzyme, such as RNA, have been experimentally shown to "reproduce," and in the Precambrian environment, such solutions could have formed the molecular beginnings of life (Eigen et al., 1981).

Many Precambrian marine microfossils are similar to microbes that live in soils, expecially those of deserts (Campbell, 1979). For example, Eoastrion is a stellate microfossil with an opaque central body from the $2.0 \mathrm{Ga}$-old Gunflint Chert of Minnesota. It is virtually identical in morphology to the living manganese-fixing bacterium Metallogenium (Barghoorn, 1977). Kakabekia is another, presumably marine, Gunflint microfossil very similar to modern soil microbes (Siegel, 1977).

Direct evidence of Precambrian soil life such as microfossils or remnants of organic carbon from kerogen is currently meagre. Cherts that fill cracks in basement rocks underlying the 2 Ga-old Pokegama Quartzite of Michigan, contain microfossil nostocalean cyanobacteria and also possible budding bacteria (Cloud, 1976). However, it is not known whether these micro-oganisms lived in cracks within a rocky soil, or in the intertidal or subtidal zone in which the overlying marine rocks were deposited. Hallbauer and van Warmelo (1974) described micro-organisms from an inter- to supra-tidal facies of the Witwatersrand Group of South Africa $(2.3-2.7 \mathrm{Ga})$. Although the observed structures themselves are probably artifacts of their preparation procedures (Cloud, 1976; Barghoorn, 1981), the carbon itself is probably biogenic. Analyses of the $2.4 \mathrm{Ga}$-old paleosols developed in Ontario on the unconformity between the Huronian Sequence and the overlying non-marine rocks have also revealed traces (from 0.014 and 0.25 weight percent) of organic carbon (Gay and Grandstaff, 1980).

There are other possible indications of Precambrian soil life. Soil micro-organisms and associated organic matter would be expected to promote resistance to erosion and a characteristic soil structure known as tilth, which is distinct in appearance from the blocky, cracked clays, of many brick pits and desert badlands. In soils, small aggregates of clayey soil material (peds) are stabilized by coatings or modified surfaces (cutans) containing polysaccharides, iron oxides and other materials.

The difference between stable soil structure (tilth) and blocky clay is strikingly shown in a 2.2 Ga-old paleosol developed on basalt in South Africa (Fig. 4). The AC horizon here is transitional between the blocky, clayey $\mathrm{C}$ horizon and the stable Al horizon. It shows thick, lamellar illuviation argillans around blocky subangular peds. The Al horizon of this paleosol has some recognizable sedimentary layering, and also some fine ellipsoidal aggregates (crumb peds), stained with iron and manganese (ferrimangans). The botryoidal nature of this stain and its development on the tops (but not the bottoms) of the peds (Fig. 5) are very like modern desert varnish, thought to be produced by bacteria and fungi (Dorn and Oberlander, 1981; Staley et al., 1982).

\section{Evidence of Early Atmospheres}

It is thought that life originated more than 3.5 billion years ago when the atmosphere may have been almost entirely devoid of free molecular oxygen. The composition of this primitive atmosphere was then altered by photodissociation of water vapor followed by the escape of hydrogen and by the production by photosynthetic organisms of oxygen. The evolution throughout time of the partial pressures of oxygen, ozone, methane, carbon dioxide and other gases in the earth's atmosphere has long been a topic of study and discussion (Holland, 1962, in press; Cloud, 1976; Clemmey and Badham, 1982; Schopf, 1983). Research on Precambrian paleosols may prove relevant in this regard.

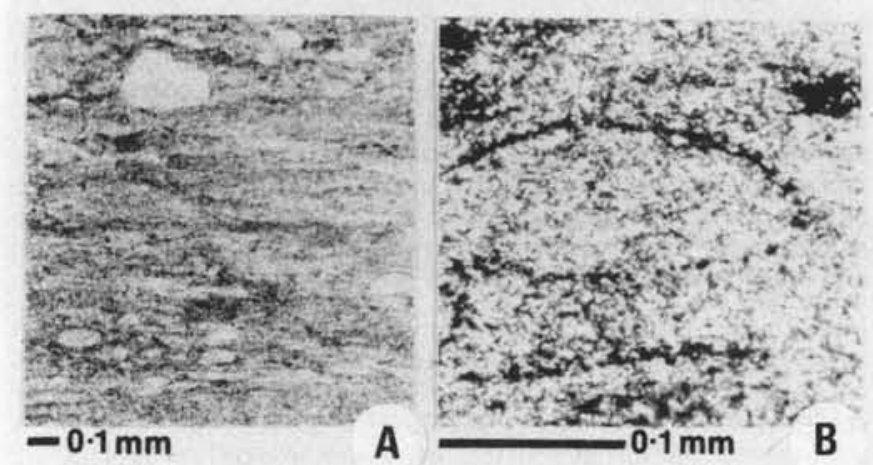

Figure 5: Relict bedding and granular crumb peds (A) with botryoidal ferrimangans $(B)$ in the $A l$ horizon of the paleosol depicted in Figure 4 (photo by G.J.R.).

Paleosols may yield evidence, for example, of the oxidation state of the Precambrian environment in which they formed. During weathering under oxidizing conditions, iron liberated from primary minerals will be oxidized to the trivalent, ferric state. Oxidized iron will be precipitated and retained as ferric oxides (hematite), hydroxides or oxyhydroxides (goethite), producing soils and paleosols with a red, brown or yellow colour. Retention of ferric iron increases the $\mathrm{Fe}^{3+} / \mathrm{Fe}^{2+}$ ratio in the soil relative to the parent rock. In contrast, under reducing weathering conditions, iron liberated is primarily in the divalent, ferrous state. Ferrous iron species are more soluble, and the dissolved iron can be lost from the soil into groundwater, creating iron-depleted soils. In poorly drained soils ferrous iron is retained in pyrite or ferrous silicates. Retention of the ferrous iron results in decreased $\mathrm{Fe}^{3+} / \mathrm{Fe}^{2+}$ ratios in paleosols relative to the parent rock.

The high content of ferrous minerals such as chlorite or pyrite gives the paleosol a drab, grey or black colour. However, because ferric/ferrous ratios are highly susceptable to alteration during diagenesis, metamorphism, or recent weathering, the colour of a paleosol in outcrop should be taken only as a preliminary and not necessarily reliable indication of oxidation state. Thus, variation in iron concentration or ferric/ferrous ratio within a paleosol may indicate the oxidation state during its formation. Other elements whose mobility is also influenced by valence or oxidation state (e.g. Mn, U, V, Zn or Mo) may also be used in this fashion.

Early workers believed that the primitive anoxic or reducing terrestrial atmosphere might have persisted for billions of years after formation of the planet. Iron-depleted reduced paleosols are common in early Precambrian rocks (Button and Tyler, 1979; Retallack, 1981), but recent work has revealed some weakly oxidized paleosols having ages back to $3.1 \mathrm{Ga}$ (Button, 1979; Gay and Grandstaff, 1980; Schau and Henderson, 1983). The existence of weakly oxidized early Precambrian paleosols suggests that the Precambrian atmosphere did contain some free oxygen. However, other studies have found both oxidized and reduced paleosols along the same stratigraphic horizon (Kalliokoski, 1975; Gay and Grandstaff, 1980), indicating that soil formation is regulated by many interacting factors.

The critical oxygen pressure separating production of oxidized and reduced paleosols may not only be a matter of equilibrium, as previously accepted. Holland (in press) has envisaged oxidation as a secondary reaction occurring after iron is released by dissolution of iron-bearing minerals in soil solutions rich in carbonic acid derived from atmospheric carbon dioxide. He argued that weathering in the presence of high atmospheric $\mathrm{O}_{2} / \mathrm{CO}_{2}$ ratios (the present condition) would first exhaust the carbonic acid content of soil solutions. 
With oxygen still present in soil solutions, oxidized soils would result. At lower $\mathrm{O}_{2} / \mathrm{CO}_{2}$ ratios oxygen might be exhausted first, leading to the formation of reduced paleosols. He further suggested that it takes more oxygen to alter the $\mathrm{Fe}^{3+} / \mathrm{Fe}^{2+}$ ratio and redden high-iron ultramafic and basaltic rocks than low-iron granitic or gneissic rocks. Under present conditions both granitic and basaltic soils are oxidized and reddened by ferric oxides; however, under lower atmospheric oxygen pressures granitic soils might be oxidized and basaltic and ultramafic soils reduced.

In examples ranging in age from 2.5 to $1 \mathrm{Ga}$, drab paleosols are developed on mafic rocks and slightly oxidized paleosols on felsic parent materials (Williams, 1968; Gay and Grandstaff, 1980; Kalliokoski, 1975). At first sight this also appears to be an indication of lower partial pressures of oxygen in the ancient atmosphere. However, for each paleosol there are complicating factors. Drab soils, containing minerals with reduced iron-bearing minerals such as pyrite and siderite are found even today where atmospheric oxygen is excluded by waterlogging in marshes and estuaries (Coultas, 1980). Some early Precambrian soils may have been waterlogged and formed in low areas where they would be especially favoured for burial and preservation. The relatively large proportion of reduced early Precambrian paleosols found may reflect this preservational bias (Gay and Grandstaff, 1980).

Waterlogging does not, however, seem to have affected a 2.2 Ga-old paleosol from the Transvaal (Button, 1979). This paleosol has prominent clastic dikes of sandstone and a hummock-and-swale (gilgai) structure in the A horizon (Fig. 4). These are both features of modern, well-drained deeply cracking, clayey Vertisols (Stace et al., 1968). Evidence of this type is needed to establish whether paleosols were waterlogged before they can be considered indicators of atmospheric composition.

Many of the mafic parent materials of Precambrian paleosols are finer grained than are the felsic rocks from which other paleosols along the same unconformity are derived. The soils produced on basic rocks also consisted primarily of clays and so were poorly ventilated compared to the sandy soils produced on quartz-bearing granitic rocks. As in modern soils such fine-grained and relatively impermeable materials would be an additional hindrance to their weathering and oxidation by diffusion of gases from the atmosphere into the soil (Birkeland, 1974; Brewer, 1976).

\section{Conclusions}

The nature of soil biota and atmospheres are only two of many unsolved questions for which paleosols are promising sources of evidence. Others include the role of Precambrian pedogenesis in creating ore deposits, long term changes in soil-forming processes and interpretations of paleoclimate, paleogeography and paleotopography from Precambrian paleosols. These and other topics will be discussed in a fortheoming IGCP 157 workshop to be held at North Carolina State University, Raleigh, N.C. in June 1985.

Precambrian research has become multidisiplinary in recent years. Important contributions to the understanding of Precambrian environments have come from stratigraphy, geochronology, paleobiology, biochemistry and geochemistry. To this list can now be added paleopedology!

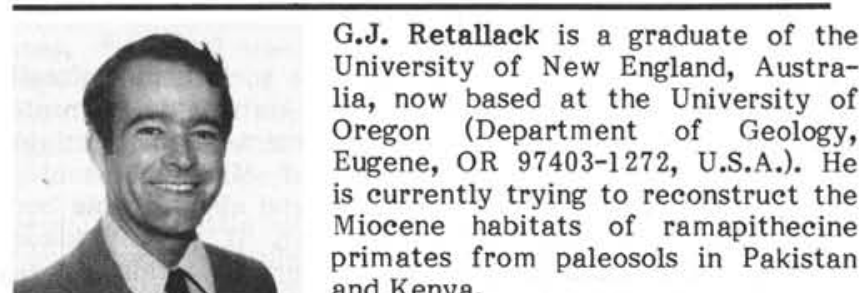
and Kenya.

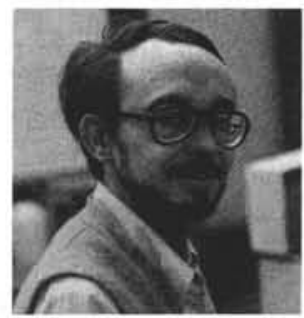

D.E. Grandstaff teaches Geology at Temple University (Philadelphia, PA 19122 , U.S.A.). His present research concentrates on dissolution kinetics and weathering of silicate minerals and their implications for the Precambrian atmosphere. $\mathrm{He}$ is also working on hydrothermal experiments simulating processes in nuclear waste disposal.

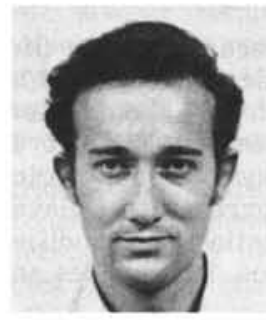

M.M. Kimberley is based in the Department of Marine, Earth and Atmospheric Sciences at North Carolina State University (Box 8208, Raleigh, NC 27695, U.S.A.). $\mathrm{He}$ taught at the University of Toronto before moving to North Carolina, where he works on the geochemistry of ironstone, sedimentary uranium deposits, phosphorites and paleosols.

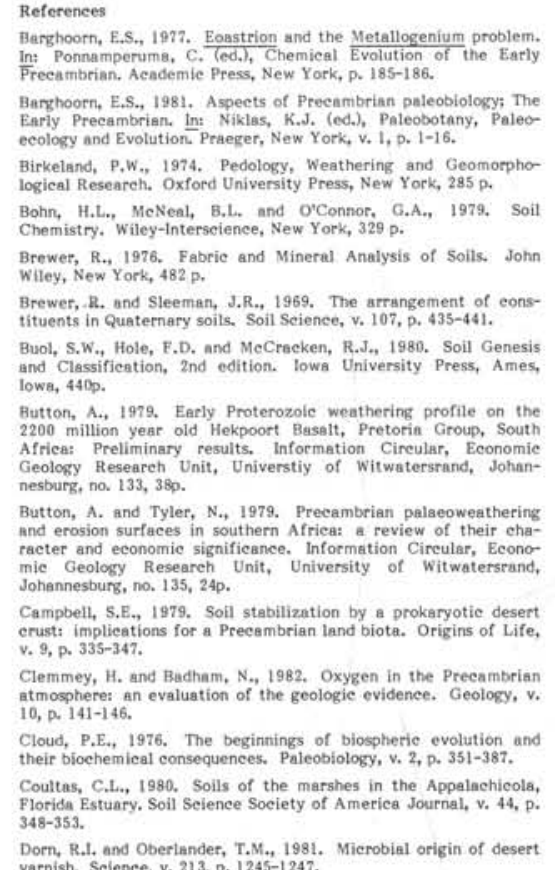

Barghoorn, E.S., 1972. Eoastrion and the Metallogenium problem.
IIn: Ponnamperums, C. ie Press, New York, p. 185-186.

inghoorn, E.S., 1981. Aspeets of Precambrian paleobiology; The ecology and Evolution. Praeger, New York, v. I, p. 1-16.

Birkeland, P.W., 1974. Pedology, Weathering and Geomorpho-

Bohn, H.t.., MeNeal, B.L., and O'Connor, G.A., 1979. Soil

Brewer, R., 1976. Fabric and Mineral Analysis of Solis. John

Brewer, R. and Sleeman, J.R., 1969. The arrangement of eons-

Buol, S.W., Hole, F.D. and MeCracken, R.J., 1980. Soil Genesis and Classification, 2nd edition. lowa University Press, Ames, Arfica: Preliminary results Information Circular, Economic Geology Research

Button, A. and Tyler, N., 1979. Precambrian palaeoweathering racter and economic significance. Information Cireular, Econoohannesburg, no. 135, 24p.

Campbell, S.E., 1979. Soll stabilization by a prokaryotic desert 9, p. 335-347.

Clemmey, H. and Badham, N., 1982. Oxygen in the Precambria 0, p. 141-146.

Cloud, P.E., 1976. The beginnings of biospheric evolution and
their biochemical consequences. Paleobiology, $v_{2} 2$, p. 351-387. Coultas, C.L., 1980. Soils of the marshes in the Appelachicola, 48-353.

Dorn, R.t. and Oberiander, T.M., 1981. Mierobial origin of desert

Eigen, M., Gardiner, W., Schuster, P. and WinklerOswatitseh, R. 1981, The origin of

Gay, A.t. and Grandstaff, D. E, 1980, Chemistry and mineralogy of Precambrian paleosols at Elliot Lake, Ontario, Canad. Precambrian Research, v. 12, p. 349-373.

Hallbauer, D.K. and van Warmelo, K.T., 1974. Fossilized plants in Africe. Precambrian Research, v, 1, p. 199-212.

Holland, H.D., 1962. Model for the evolution of the Eart atmosphere. Int Engel, A.E.J., James, H.L. and Leonard, B.F. (eds.), Petrologic Studiest A volume of honor A. F. Buddington.

Holland, H.D., in press. Chemical Evolution of the Atmosphere and Ocenns. Princeton University Press, 656p.

Jenny, H., 194i. Factors of Soil Formation. MeGrawHill, New York, 281p

Kalliokoski, J., 1975. Chemistry and Mineralogy of Precambrian paleosols in northern Michigan. Geological Society of America Bulletin, v. 86, p. 371-376.

Kalliokoski, J., 1977. Chemistry and mineralogy of Precambrian paleosols in northern Michigan: reply. Geological Society of

Kroonenberg, S.B., 1978. Precambrian palaeosols at the base of the Roraima Formation of Surinam. Geologie en Mijnbouw, v. 57,

LeCheminant, A.N., Ashton, K.E., Chiarenzelll, J., Donaldson, J.A., Best, M.A., Tella, S. and Thompson, D.L., 1983. Geology of Aberdeen Lake map area, District of Keewatin: Preliminary report. In: Geological

Marbut, C.F., 1935. Atlas of American Agriculture. Part III. Soils of the United State

Niviforoff, C.C. 1943 . Introtuetion to peleopedology. Amerien Nikiforoff, C.C., 1943. Introduetion
Journal of Seience, v. 241, p. 194-200.

North American Commission on Stratigraphic Nomenclature, 1983. North American stratigraphic code. American Association
of Petroleum Geologists, v. 67, p. $841-875$.
Nussinov, M.D. and Vekhov, A.A., 1978. Formation of the early Earth regolith, Nature, $v, 275, p, 19-21$.

Ortlam, D., 1971. Paleosols and their signifieance in stratigraphy and applied geology in the Permian and Triassic of southern GerDanting of Paleosols. international Society for Soil Seience and Israel University Press, Jerusalem, p. 321-327.

Rankama, K., 1955. Geologic evidence of chemical composition of the Precembrian atmosphere. In: Poldervaart, A. (ed.), Crust Denver, Colorado, p, 651-664.

Retallack, G.J., 1981. Fossil Soils: indicators of encient terrestrial environments. In: Niklas, K. J. (ed.), Paleobotany,
Paleoceology, and Evolution. Praegef, New York, p. Ss-102. Retallack, G.J., 1983. Late Eocene and Oligocene paleosols from America Special Paper 193, 82p.

Sehau, M. and Henderson, J.B., 1983. Arehean ehemica: weathering at three localities on the Canadian Shieid. PrecamSehopf, J.w. (ed.), 1983. Earth's Earliest Biosphere: Its Origin and Evolution. Princeton University Press, Princeton, N.J., 543 p. Sehumm, S.A., 1977. The Fluvial System. John Wiley, New York,

Siegel, B.Z., 1977. Kakabekia, a review of its physiological and effinities, In: Ponnamperuma, C. (ed.), Chemical Evolution of the Early Precambrian. Academic Press, New York, p. 143-154. Stace, H.C.T., Hubble, G.D., Brewer R., Northeote, K.H., Sleeof Australian Soils. Rellim, Adelaide, $435 \mathrm{p}$.

Staley, J.T., Palmer, F. and Adams, J.B., 1982. Mierocolonial fungi: common inhabitants on desert rocks? Science, $v_{2} 215$, p.

Willams, G.E., 1968. Torridonian weathering, and its bearing on Torridonian palaeoclimate
Geology, v. 4, p. 164-184. 